\title{
From Marginality to Mattering: Linguistic Practices, Pedagogies and Diversities at a Community-Serving Senior College
}

\author{
Hannah Göppert \& Andrea Springirth \\ Graduate Centre, CUNY, New York, USA
}

Article received 25 January 2016, accepted 16 May 2016, final version 30 May 2016

DOI: http://dx.doi.org/10.5565/rev/jt13.678

\begin{abstract}
The cultural diversification of colleges and universities which initially targeted the needs of a specific minoritized group raises questions concerning the inclusion of every individual and the maintenance of the advances which have been made for the original population. This paper provides insight into the challenges and merits at the intersection of linguistic and racial/ethnic diversification within CUNY's Medgar Evers College. Historically tied to the Black Campus Movement, the college is committed to being an agent of social transformation for the surrounding community. Aiming to understand the perspectives on language and diversity of the key stakeholders at the college, a number of semi-structured interviews were conducted. In terms of linguistic diversity, we found that there is tension between the adherence to the belief in an idealized 'Standard English', and the acknowledgement and support of linguistic variation. Regarding the college's racial and ethnic climate, a perception of exclusion among non-black students of color became evident. Existing concepts as well as promising attitudes and practices among participants indicate some ways that could encourage all students to move from the margins to the center. We suggest that educators, administrators and staff at Medgar Evers should encourage dialogue and cooperation between linguistically and ethnically diverse students, both in and outside the classroom. At the same time the safe and empowering space for black students should remain intact. We also claim that further theorization of the diversification of predominantly non-white institutions is needed.
\end{abstract}

Key words: Historically black colleges and universities, campus diversification, linguistic ideologies, racial/ethnic climate, inclusion

\section{Zusammenfassung}

Die kulturelle Diversifizierung von Colleges und Universitäten, die auf spezifischen die Bedürfnisse von Minderheiten ausgerichtetet sind, wirft Fragen nach der Inklusion jedes/jeder Einzelnen bei gleichzeitiger Bewahrung der Errungenschaften der ursprünglich adressierten Gruppe auf. Dieser Artikel gibt einen Einblick in die Herausforderungen an der Schnittstelle sprachlicher und „ethnischer" Diversifizierung am Medgar Evers College der City University of New York. Das College steht historisch dem Black Campus Movement nahe und versteht sich als Motor sozialer Gerechtigkeit in der umliegenden Nachbarschaft. Durch eine Reihe von Interviews mit den Hauptakteuren des Colleges gewannen 
wir einen Eindruck vom Umgang mit Diversität. Hinsichtlich sprachlicher Diversifizierung besteht eine Spannung zwischen dem Festhalten an einem idealisierten „Standardenglisch“ einerseits, und andererseits der Anerkennung von sprachlicher Vielfalt. Außerdem zeigte sich, dass einige Studierende of Color sich von der Mehrheit der Schwarzen Studierenden ausgeschlossen fühlten. Bestehende Konzepte sowie vielversprechende Einstellungen und Praktiken unserer Befragten lassen Wege erkennen, wie alle Studierenden inkludiert werden können. Wir empfehlen, dass Pädagog*innen und (Verwaltungs-)mitarbeiter*innen innerhalb und außerhalb des Unterrichts Dialog zwischen sprachlich und „ethnisch“ diversen Studierenden anregen sollten. Zugleich sollte jedoch der geschützte und empowernde Raum für Schwarze Studierende beibehalten werden. Weitere Konzeptualisierung der Diversifizierung von mehrheitlich Nicht-Weißen Institutionen ist erwünscht.

Schlüsselwörter: Diversifizierung von Universitäten, sprachliche Ideologien, „ethnische“ Beziehungen, Inklusion

\section{Resumen}

La diversificación cultural de universidades dirigidas en sus orígenes a las necesidades de una minoría provoca preguntas acerca de la inclusión de cada individuo mientras que se mantengan los avances logrados para la población original. Este artículo investiga la intersección de la diversificación lingüística y racial en Medgar Evers College de la Universidad de la Ciudad de Nueva York (CUNY). Históricamente conectado al Black Campus Movement, la institución está comprometida con ser un agente de la transformación social en la comunidad de Brooklyn. Para comprender las diferentes perspectivas sobre lengua y diversidad, entrevistamos a algunos representantes de los principales grupos de la universidad. Acerca de la diversificación lingüística se mostró una tensión entre la convicción de que existe un inglés normativo o 'ideal' y el reconocimiento de la variación lingüística. Con respecto al clima racial y étnico, se manifestó una percepción de exclusión entre estudiantes de color que no se identificaban como negros. Conceptos existentes así como las buenas actitudes y prácticas entre los participantes prometen caminos que podrían apoyar a todos. Sugerimos que educadores, administradores y empleados en Medgar Evers deben fomentar el diálogo entre estudiantes diversos, tanto en las aulas como fuera de ellas. Al mismo tiempo, se debe mantener el espacio seguro y la atmósfera de empoderamiento creado para los estudiantes negros. También recomendamos más conceptualización teórica sobre la diversificación de instituciones no-predominantemente blancos.

Palabras claves: Diversificación de la educación universitaria, ideología lingüística, clima racial, inclusión 
"In our lives we all fluctuate from mattering to-marginality to mattering. ... So everybody feels marginal at different times in your life. ... So the positions that I've been in, my whole thing is understanding. How I move my students, or how do I move individuals who feel marginal to mattering? ... That has been my life's work. ... Because every human being, I don't care who you are, what you do, needs to feel like they matter."

- Gladys Palma de Schrynemakers

\section{Introduction}

As part of an ongoing oral history project through the CUNY Futures Initiative, the authors of this article set out to conduct a series of interviews regarding the linguistic experiences of students, professors, and staff at Medgar Evers College ${ }^{1}$ in Brooklyn, New York. Through this research opportunity, we hope to give our participants a space to voice their interests and experiences and encourage them, as well as our readers, to think critically about how diversity is being managed at Medgar Evers and in educational institutions in general in order to work towards more inclusive pedagogies.

Throughout the oral history interviews conducted, however, students, professors, and staff shared more than their linguistic experiences. They also shared stories regarding race, ethnicity, identity, marginalization, change, tension, and solidarity. Founded at the end of the Civil Rights era and in the spirit of the Historically Black Colleges and Universities (HBCU), Medgar Evers has an historic commitment to serve populations previously excluded from higher education and to cultivate the cultural and academic development of its students and communities (Hurtado, Milem, Clayton-Pedersen, \& Allen, 1998; Medgar Evers College, n.d.b). Although the institution's historical legacy of "educate to liberate" permeates throughout the school, broader developments often embedded in the political economy pose challenges to its strong sense of "Medgar Identity" based on African American and Afro-Caribbean experience and history.

Immigration, community (re)organizing, campus infrastructural developments as well as the standardization of education - noticeable in increasing unification across CUNY campuses have attracted more non-black students of color ${ }^{2}$ to Medgar Evers, who often also come from underrepresented and disadvantaged backgrounds. Confronted with the restructuring of student enrollments and the voiced concerns of those who have been a part of the school for quite some 
time, though not completely integrated (i.e. Latin@ students), the school has had to address the experiences, language use, needs, and attitudes of a wide range of English speakers and speakers of languages other than English. Based on the interviews we collected we found that there are certain discrepancies between the college's commitment to social transformation and reality. Especially among students who do not identify as black, one common notion seems to be a sense of exclusion from the college community. Therefore, one of Medgar Evers' biggest challenges is to operationalize and bridge the gap between its emancipatory goals and everyday practices. The main question we attempted to address after conducting the interviews was: How can the institution employ pedagogies that support and value every student, irrespective of his or her race, ethnicity or language, while maintaining its legacy of the Civil Rights Movement and focus on Afrocentrism (Ippolito, 2007; Hurtado et al., 1998)?

While this article focuses on the case of Medgar Evers College, many institutions with similar historical legacies and demographics are facing the same challenges (Oguntoyinbo, 2015). Our exploratory study therefore also aims to generate questions for further research and to contribute to a broader conversation about the interconnections between differences and inequalities in higher education, including those that relate to gender, class, ethnicity, language, and the diversity of identities and positionings in the classroom (Ippolito, 2007, p. 752).

The first section of this paper will provide some background on the school, its demography and its history. Although this section mainly draws from information the college has published, it will also include quotes from our interviews to provide insights and illustrations of the school that the official data does not offer. It will then introduce the research methodology and interviewees and give a brief introduction to the theoretical concepts that informed our research. The second part of the paper will address the linguistic practices and pedagogies revolving around language at the college. It will focus on the coexistence and the (de)valuation of the different varieties on campus and in the classroom, the need to teach and learn 'Standard English' while still viewing students' linguistic repertoires as resources, as well as the challenges this poses for educators. The last section of the paper will take into consideration Medgar Evers' racial and ethnic diversification. 


\section{Medgar Evers and Crown Heights}

Medgar Evers College is a four-year senior college located in Crown Heights, Brooklyn, a predominantly black neighborhood and home to a large Caribbean community. The college was founded in 1969 in response to demands from the central Brooklyn residents and communitybased organizations' desire for a local public college that would emphasize a strong commitment to the neighborhood (Medgar Evers College, n.d.a). The college's "sense of commitment and service to the community" is directly attributed to the multi-faceted roles representatives of the local community have played in its establishment, growth, and development. Named after the martyred civil rights leader Medgar Wiley Evers (1925-1963), the college hopes students and faculty will continue to be motivated by his contribution to "the cause of human freedom and dignity" (Medgar Evers College, 2013). It is Medgar Evers' aspiration to serve its predominantly black community and "educate to liberate." This mission must be positioned in the context of the Black Campus Movement and Black Studies Movement, two of the many movements that together comprised the Black Power Movement during the Civil Rights era. The nationwide struggle for Black Studies sought to introduce the Black Studies discipline into K-12 schooling and higher education (Rogers, 2012, p. 21-22). The objective of the Black Campus Movement was to create "Black Universities", educational institutions governed by blacks that educate black students about their experience from their perspective and give them tools to advance themselves and their communities (Rogers, 2012, p.22). Today, with over $87 \%$ of its student population selfidentifying as "black" (CUNY Office of Institutional Research and Advancement, 2015), the legacy of the Black Campus Movement is visible in many aspects of Medgar Evers's mission, past and present. Some of the college's present goals are described as follows:

to serve the Central Brooklyn community which is comprised of students with diverse educational, socio-economic, political, cultural and national backgrounds; to improve students' understanding of self, past, and present societies...by providing its students with a liberal education which communicates the knowledge of tradition....and the beauty and profundity of their cultural heritage; and to prepare students to be energizers of change or change agents in the community. (Medgar Evers College, n.d.b) 
This mission translates into the curricula as well as into the college's identity. Our interviewee, Martina, for instance emphasized: "At Medgar, the openness to speak out even if people disagree with you, that's something I really appreciate and I think it comes from the social protest and the civil rights experience deeply rooted in the institution, you know this right to express your opinion."

As it is Medgar Evers' pronounced aim to serve an "underserved" community, it maintains an open admission policy, which only requires students to possess a high school diploma or General Educational Development (GED) equivalent. In 2014, more than 90\% of all applications were accepted and two thirds of the students received financial aid (Bailey, n.d.). The students we interviewed mentioned the support they received during the application process and the financial aid consulting available.

Thanks to its commitment to social mobility, it can be said that Medgar Evers offers quality education to groups who historically had, and continue to have, more difficulty accessing higher education. It is especially remarkable that it challenges the normalization of whiteness in American educational institutions (Banks \& McGee Banks, 2012) by placing the African American experience at the center.

Despite the understanding of Medgar Evers as a black institution, it is not entirely segregated. According to CUNY's enrollment statistics there are currently just over $12 \%$ of students at Medgar Evers who do not identify as black. The largest ethnic group among them are Hispanic students (7.6\%); the percentage of white students remains very small (1.9\%) (CUNY Office of Institutional Research and Advancement, 2015). The staff members who have been at the college for a longer period of time have observed a slow racial diversification. John and Gabriela, two more of our interviewees, agreed that the faculty is undergoing a comparable process and highlight the increasing number of Asians and Latin@s among the faculty.

The growing heterogeneity of Medgar Evers is driven by changes within the school, but is also linked to economic and demographic changes in the wider community, which are connected to broader political and economic developments. On the level of the institution itself, Medgar Evers' new president is mentioned to be giving the college a new direction. According to staff 
members, the college's reputation has changed and attracted students from China, India, Russia, Latin America, and elsewhere. They described the construction of Medgar Evers' new science building and new library as initiators of change, which improved the college's physical attractiveness. In addition, Crown Heights, the neighborhood where Medgar Evers is located, and the entire borough have changed demographically due to immigration and gentrification in the last decades (Furman Center, 2015). Our interviewees who witnessed these developments over a longer period of time did not parallel the changes of the neighborhood to those in the college. But respondents agree with broader studies on the changing face of Brooklyn, which have found that the area is perceived safer and hence become more accessible (City of New York, 2016). Another factor that drives change at Medgar Evers is the increasing standardization of higher education. In the context of the broader CUNY system, the unification that is occurring through the "Pathways Initiative" may be a response to effects of neoliberalism on institutions, particularly the increasing application of entrepreneurial business strategies onto public universities (Holborow, 2015).

As will be shown throughout the article, the linguistic, racial and ethnic diversification of Medgar Evers can negatively affect the campus climate and the sense of belonging of students who see themselves in a minoritized position within the college community when not met with teaching strategies that encourage student voice and enhance students' critical understanding as global learners (Ippolito, 2007, p. 752).

While Medgar Evers has never been a college solely attended by black students, changing demographics and standardization in education are likely to continue and further diversify the student population of a college that is situated in a borough that is home to people of many different ethno-linguistic groups. Therefore, it is important to engage in a critical conversation about the challenges that the original focus of the college poses to the maintenance of a truly inclusive and empowering educational space for all students. This article aims to contribute to this discussion. 


\section{Methods}

As part of the CUNY Futures Initiative project, one of the main goals of our project was to collect qualitative data on CUNY campus linguistic experiences in order to supplement the quantitative data available regarding the different languages spoken on each campus. As an extension to this, our project aimed to facilitate, and report on, an indirect dialogue between students, faculty, and administrators at Medgar Evers to inform pedagogical development (Ippolito, 2007, p. 752). The approach here has been to conduct an exploratory case study of individuals' unique linguistic ideologies and experiences at the college through linguistic biographies and oral histories of those who have witnessed developments in the college and surrounding neighborhood. Interviewees were chosen through a combination of snowball sampling and convenience sampling. We strived to gain broader insights by selecting interviewees in different positions at the college - students, administrators, staff, and professors as well as persons from different linguistic and ethnic positionalities. Although we aim to highlight diverse voices from across the campus, it does not lie within the spectrum of this study to make representative claims about the school population.

This study centered on eleven interviewees: one administrator, two staff members, three professors, and five students. For all participants, except the administrator who explicitly stated her desire to be named, we have assigned them pseudonyms. The administrator, Gladys Palma de Schrynemakers, is Medgar Evers' new Vice President and Associate Provost. Our three staff members, Jian, Mihir, and John, two professors, Gabriela, and Martina, and five students, Kalisa, Adilene, Sanya, Salmah, and Adah, all come from a multiplicity of backgrounds with diverse linguistic repertoires. We captured their perspectives in semi-structured interviews that took place in staff offices and the college's cafeteria and lasted between 20 minutes to one hour. Two of the interviews were focus-group conversations that each included two students. In addition to our interviews, we also utilized online testimonials of Medgar Evers' Latin@ students from the website of the Association of Latino American Studies (ALAS) ${ }^{4}$. Responses from all of our participants and sources offered rich insight into school policy, practice, and interactions, and highlighted different linguistic, racial/ethnic, and pedagogical ideologies, social relations, and 
cultures. We are aware of and have reflected on the structural concerns with the interviews, namely the place, time, setting, presence of interviewers and recorders, purpose of the interview, set of specific questions, as well as our own linguistic conventions, cultural assumptions, and identities that impact our ontological positionings, questions, and responses (Ippolito, 2007, p. 752). We are aware that our presence might have constrained some narrators' comfort, and that the setting and context of the interviews might have hindered some from saying more, or contrarily may have pressured some into saying what they felt they "should" or "must" say (Shopes, 2002). Although several of our questions focused on linguistic experiences, each interview was shaped by other factors inextricably linked to linguistic issues, such as race and ethnicity. Specifically, we asked questions regarding biographical information, relationship to the college, linguistic and educational background, and community and school outlook. It is our goal to inform pedagogical practices, address both questions and solutions regarding the maintenance of an inclusive working and learning environment that merit the attention of Medgar Evers and the wider CUNY community, and help higher education "achieve its responsibility for advancing social progress" (Hurtado, 2007).

Before the research results are presented in more detail, we will briefly touch on key concepts that have informed our analysis.

\section{Theoretical Backdrop}

For assessing the linguistic landscape of Medgar Evers, we have gained much from the concept of language ideology. According to Blommaert, it "stands for socially and culturally embedded metalinguistic conceptualizations of language and its forms of usage" (2006, p. 241). It is particularly useful because it permits relating communicative practices and beliefs in the college to "considerations of power and social inequality" and broader "macrosocial constraints on language behavior" (Woolard, 1998, p. 27). In addition, the notion of "translanguaging" aids in our analysis of the various language practices and ideologies we observed at Medgar Evers. Originally conceived of in Welsh by Cen Williams, and further advanced by Ofelia Garcia and Li Wei (2014), translanguaging postulates that "bilinguals have one linguistic repertoire from which they select features strategically to communicate effectively and takes as its starting point the 
language practices of bilingual people as the norm, and not the language of monolinguals" (Celic and Seltzer, 2011, p. 1).

In terms of the college's racial/ethnic climate, our analysis is informed by the notion that "perceptual differences of college experience" matter because they can strongly affect an individual's attachment to the institution and academic success (Hurtado et al., 1998). Hence, we consider it important to give a voice to the experiences of underrepresented students and to take their concerns seriously. We will analyze the perception of the racial climate at Medgar Evers by non-black students of color with the help of Smedley, Myers, and Harrell's (1993) concept of "minority stress status", which maintains that underrepresented groups experience psychological stress that negatively affects their academic achievements. In addition, we draw from Sylvia Hurtado's extensive scholarship on racial/ethnic diversification in higher education $(1998,2007)$. Hurtado and colleagues emphasize the range of advantages of campus diversity and suggest that institutionally facilitated inter-group communication and interaction contributes to a positive campus climate, hence minimizing feelings of marginalization (1998, p. 294).

These frameworks can inform and help Medgar Evers and other CUNY campuses work towards a more inclusive education. Yet, taking into consideration that conceptualizations of campus diversification usually concentrate on predominately white institutions and being aware of our own positionalities as an external all-white team of researchers, we do not aim to suggest that these concepts should be directly transferred to Medgar Evers, but we want to point to elements within them, which can encourage dialogue and development of educational policies at the college. More importantly, we seek to highlight already existing positive practices at Medgar Evers - actions of individuals and groups which deserve more attention and could become examples for further valuation of the college's racial/ethnic diversity.

\section{The Linguistic Landscape at Medgar Evers}

Of the eleven participants interviewed, ten stated that they were multilingual. This attests to the remarkable linguistic diversity at Medgar Evers. Below is a table containing the linguistic repertoires and school positions of each interviewee. 
Table 1: Interviewee Linguistic Repertoires and School Positions

\begin{tabular}{lll}
\multicolumn{1}{c}{$\begin{array}{c}\text { Interviewee } \\
\text { (Pseudonym) }\end{array}$} & \multicolumn{1}{c}{ Position at ME } & \multicolumn{1}{c}{ Language(s) Spoken } \\
\hline Gladys & Administrator & Spanish (Cuba), English \\
\hline Jian & Staff & Cantonese, Mandarin, English \\
\hline Mihir & Staff & Bengali, Hindi, Urdu, English \\
\hline John & Staff & English, Jamaican Patois (formal) \\
\hline Gabriela & Professor & Spanish (Colombia), English \\
\hline Martina & Professor & Spanish (Spain), French (unspecified), German, English \\
\hline Kalisa & Student & Jamaican Patois (community dialect), English \\
\hline Adilene & Student & English, Turkish \\
\hline Sanya & Student & English, Syrian Arabic \\
\hline Salma & Student & English \\
\hline Adah & Student & English, Spanish (Colombian), Egyptian Arabic
\end{tabular}

Due to the complex and controversial status of many languages, surveys and other quantitative studies often overlook important details. Additionally, a survey that only recognizes standardized languages would ignore as much as half of these languages. Yet participants readily discussed similarities, differences, and conflicts across related varieties. Furthermore, many of these languages were not encountered through direct questioning, but were revealed as participants shared their stories.

A recurring theme across the interviews was the changing linguistic landscape at Medgar Evers. Although linguistic diversity is widely viewed as an asset, it does not come without problems. Gabriela and some of her colleagues have struggled to find a balance between accepting and promoting language diversity and preparing students for the world outside of college. The professors' struggles can be explained within the framework of language ideology. Blommaert argues that language use is ideologically stratified and regimented (2006). The distinction and hierarchical positioning of different languages or language varieties is embedded in broader power structures in society (Blommaert, 2006). A particularly powerful construct is the notion of a 'standard' as the variety that is most highly valued. Standard Language Ideology 
is "a bias toward an abstract, idealized homogeneous language, which is imposed and maintained by dominant institutions and which has as its model the written language, but which is drawn primarily from the spoken language of the upper middle class." (Lippi-Green, 1997, p. 64). In contrast to this abstract ideal, linguists agree that variation is intrinsic to all spoken language (Tollefson, 2000).

The professors we interviewed do not necessarily recognize Standard English as the 'best' variety. But cognizant of society's dominant language ideology, they are facing a conflict - if they do not insist that students learn Standard English this may impact their career after graduation. This reflects Tollefson's argument that language ideology can determine who has access to resources (2000). Both Gabriela and Martina noted that students who are aspiring to be ESL teachers are expected to be excellent Standard English users. In addition, Gabriela repeatedly expressed her internal conflict between wanting to affirm her students' language varieties, but at the same time believing that emergent English and non-standardized English speakers need to achieve proficiency in Standard American English.

Gabriela is not alone in her conflicting ideologies and she believes that many of her colleagues are not even aware of their biases against students who do not conform to the standard. Instead, practices are exacerbating "linguistic micro-aggressions" (Charity Hudley \& Mallinson, 2013) against minoritized populations. Such acts are not only perpetrated by educators onto students, but also by students onto others. Salma, a student, reflected on her experience with professors: "Professors with heavy accents I hate. You get Chinese, African accents from staff...One professor's Chinese accent is so heavy. You ask him 'What?' and he's so rude." Salma's pejorative perception of non-standard and non-native English appears to reproduce the dominant language ideology in the U.S. and its educational institutions. In order to challenge hegemonic conceptions of language quality, value, status or function (Blommaert, 2006) professors should be both teaching and showing tolerance for language variation early and often. In this way, students who encounter differences will not see barriers to comprehension but opportunities for expanding student-teacher dialogue. 
In a country where university education is a major factor in upward mobility, colleges serve as gatekeepers, preventing access to knowledge and class advancement for those who do not assimilate to ethno-linguistic norms. In one statement written on the Medgar Evers Association of Latin American Studies (ALAS n.d.a) webpage, a student named Stephanie wrote: "Because of my Latino accent, and because most of the time I make grammatical errors when I speak, one of the professors... treated me as if having an accent and making errors is unacceptable....". Stephanie's experience highlights the challenges expressed by Gabriela. In many classes at Medgar Evers, students' knowledge and quality of work are judged not based on how they work, but on how they speak.

It is disingenuous to expect students to respect the linguistic diversity of their peers when this diversity is not tolerated in the classroom. If failure to attain a particular linguistic standard prevents students from participating in discussions, or from reaching crucial benchmarks, such as passing classes or obtaining a degree, people are inevitably going to associate minoritized languages and non-standardized Englishes with failure and lack of education. This kind of banking model of education, as Freire calls it (1970/2000), in which students are treated as containers in which to deposit knowledge, rather than participants in knowledge production, puts students in a position where they must decide between denying a part of their identity and denying their right to an education. Flores and Rosa (2015) argue that when a minoritized speaker speaks, their language is often racialized regardless of how accurately it reflects the language standardized by white middle-class speakers. This reflects Gladys's sentiments about the minoritization of her English as a student: “...in high school a nun said to me, 'really? English is your second language? You speak so well!'...Does it scar you? Absolutely. Does it tear at you? Absolutely." Such racialization of language reinforces hegemonic power structures by making it difficult for minoritized individuals to escape both personal and educational evaluation of their ethno-linguistic backgrounds. Whether through the outright denial of a person's language or small, yet hostile micro-aggressions, acts against a person's language are acts which censor a person's right to free speech. 
Dominant language ideologies clearly impacted teaching at Medgar Evers and the attitudes towards linguistic diversity of our research participants. But we also observed individuals who resisted those ideologies - professors who employed empowering pedagogic strategies and attempts to increase the college's valuation of linguistic variation by its decisionmakers.

During an interview with Kalisa, a friend mentioned that Jamaican Patois, which they both spoke, was broken English. Kalisa responded: "My language is not broken. It's Patois. If you say it's broken, that means there's something wrong with it, and there's nothing wrong with it." Her favorite professor, Mr. Smith, assigned an article about the complexity of World Englishes, encouraging her to assert the validity of Jamaican Patois. Kalisa feels like her experience at Medgar Evers has been positive, in part because of the respect her teachers have shown students. Professors such as Martina are aware that multilingualism is an asset. On classroom diversity, Martina reported: "You cannot avoid it...I have these students from Nigeria and they help each other, and you cannot prevent people from using their own languages." Educators such as Mr. Smith and Martina clearly see no problem with teaching from a heteroglossic perspective, that is, by "embracing the multifaceted and multilayered plurality which [...] is inherent in living language" (Busch, 2014, p. 24, see also Bakhtin, 1981). They both discuss the importance of translanguaging and incorporate it by encouraging multilingualism during classes. Critical pedagogues at other institutions have engaged in similar linguistic practices. bell hooks, for example, regularly uses her African American English in the classroom, and she encourages her students to speak in their other languages (1994, pp. 172-175). She argues that hearing words in other languages gives students an opportunity to reflect on ambiguity and to hear language without owning or possessing speech through interpretation.

At Medgar Evers, positive attitudes toward language extend all the way up to the administrative level. Gladys affirms that multilingualism provides people a more complex perspective of cultures. Although new to the institution, she grew up in Brooklyn and has worked in education for over two decades. She plans to change educators' perspectives about emergent English learners: “Being an English learner doesn't mean that they're poor writers. It means that 
their structure is different. So then instead of saying, '...you don't know how to write English,' maybe creating projects that understands and supports language learners." Having taught and researched bilingual education, she views language learning and writing development as two related, but distinct processes. Gladys views the frequent confusion of the two as an opportunity for teachers to learn and for the university to reframe its position.

\section{Bridging the gap between the racial/ethnic diversification of Medgar Evers and its black identity}

The small but considerable number of non-black students at Medgar Evers primarily belong to groups that have also historically been underrepresented in higher education and are thus in a minority position both in U.S. society and in the college. Non-black students of color and their advocates among the staff both implicitly and explicitly addressed the racial climate on campus. In doing so, some revealed a feeling of not belonging to the community, and a notion of lacking estimation for their cultural heritage as well as their political struggles. Given the frequency and the content of this theme coming up, as well as the intersections between racial and linguistic diversity, we chose to take the challenges of racial and ethnic diversification at Medgar Evers into account in our analysis, although it was not initially part of our research agenda. Based on the material we collected and testimonies written by members of the college's Association of Latin American Students (ALAS), this section will give voice to the narratives of non-black students of color. Drawing from research on diversity in institutions of secondary education, we then discuss the need to value ethnic diversity in order to give every student adequate support. We suggest that this aspiration should not be understood as a threat to the college's identity or in contradiction with its importance as a space that puts the black experience and black history into the center. We also claim that the diversification of predominantly non-white institutions is a challenge that needs more scholarly attention.

Our attention was first drawn to this issue in noting that both of the non-black students we interviewed mentioned a certain discomfort with their college experience. Sanya, who is in her last year at Medgar Evers, stated that she had very little positive associations with the college and that her overall experience was bad. Adah remembered how she asked herself throughout the first 
year: "Is this school really for me?" She also mentioned that she usually goes "right back home" after class, without participating in clubs or socializing with other students. While both of them refrained from explaining in more detail why this was, possibly because both interviews were done in racially mixed group settings, one interviewee ${ }^{5}$ addressed the issue much more directly. According to them, Latin@ students at Medgar Evers "feel isolated because the college as a whole is afrocentric .... So that's not their experience." They also recall how some students who wanted to speak about their experience "were actually silenced, shut down, within the classroom." Two interviewees independently pointed us to the ALAS, which maintains an online archive of 26 testimonies written by members who expressed their feelings and experiences at Medgar Evers. Recurring themes include alienation and underrepresentation of the 'Latin@ experience' in college. Mabel, for instance, described her initial year in a similar fashion to our interviewee Adah: "I was the only Hispanic person in all of my classes for my first year in college. I felt as if I didn't belong." In some cases the testimonies even express that they felt discriminated against by professors or perceived a devaluation of their own experiences with racism in the U.S. The effects of the notion of feeling singled out were explained by Smedley, Myers and Harrells, who coined the concept of "minority stress status" (1993). It suggests that underrepresented populations may suffer increased psychological distress, which results in poorer academic performance. Hurtado et al. (1998) add that the heightened visibility of minorities can cause an exaggeration of group differences. This is an important consideration as the minority students' perception of being isolated from the 'black majority' emphasizes racial difference and thereby overlooks the enormous heterogeneity within the racial categories (i.e.the variety of geographic, ethnic, cultural, socioeconomic and linguistic backgrounds of the black students) and individual biographies. Observing these problems and the lack of action taken has brought one of our interviewees to believe that Medgar Evers holds on to its ideals "more in terms of theory and history than actual practice (Interview Martina, November 23, 2015).

The difficulties that Latin@ and other minority students at Medgar Evers perceive indicate that there might be a contradiction in the aim of providing the "institutional normative structures that support the advancement of African American people" (Hurtado et al., 1998), and 
the accommodation of ethnically diverse students with different backgrounds. On the one hand, little needs to be said about the educational benefits of diversity. Extensive research has shown that "all students benefit from substantial encounters with diversity" (Hurtado, 2007). Although she praises campus diversity in much of her work, Hurtado and her colleagues agree that Historically Black Colleges and Universities (HBCU) "must be maintained" due to "the positive social, psychological, and intellectual outcomes for students who attend them" (1998, p. 286). This apparent contradiction may be due to the fact that publications on campus racial climate and student diversification for obvious reasons usually concentrate on predominantly white colleges.

There is lack of a concept that harmonizes the idea of an educational space that is targeted at the needs of a specific group with the integration and valuation of students of other marginalized groups with different experiences of oppression. The challenge for Medgar Evers is thus to transform racial and ethnic diversity into an opportunity for the whole college community. We can not and do not aim to prescribe a recipe on how to solve this problem, firstly because of the fact that it is under-researched and secondly because of our own positionalities as an external all-white team of researchers. Yet considering that one of our respondents said that she felt her own action at the college was not heard enough, it is important that we raise awareness for this issue. While the accounts of students who feel excluded serve as important examples of the special challenges Medgar Evers faces as a diverse predominantly black institution, we also find a number of positive and possibly seminal practices at the college.

\section{Promising practices}

One suggestion produced by research on campus diversification is the combination of "continued support for strong ethnic identities and affiliations as well as institutional encouragement for multiracial contacts" (Hurtado et al.1998, p. 294; Duster, 1993). Chang (1996, as cited in Hurtado et al.,1998, p. 294) notes that "socializing across race and discussing racial/ethnic issues have a positive effect on students' retention, overall satisfaction with college, intellectual self-concept and social self-concept". Transferring this proposal to the context of Medgar Evers, it suggests that positive inter-group dialogue could allow students to learn about the distinct histories of different racialized groups, but also create awareness for commonalities in the struggles of 
oppressed groups. Hurtado points out that teachers and administrators have a responsibility in actively encouraging such dialogue through activities in and outside the classroom. She argues that they can thereby help students to "move ... from their provincial worldviews" (Hurtado, 2007 , p. 189) and to take different perspectives. Well-facilitated interaction could hence create a sense of solidarity and belonging among diverse students, without devaluing the experiences of anyone. According to Chang (1996), educators can create opportunities for inter-racial communication through student-centered approaches. This methodology meets the core of Medgar Evers' philosophy and is also visible in practice. While students reported that they felt supported individually by some professors, Martina confirmed that faculty really put students in the center: "I think we here at Medgar, we work much more closer to them than in other CUNY colleges. ... Here you really get to know the students."

Besides the encouragement of dialogue between peers, it should also be seen as a task for all staff to maintain a college environment that is positively encouraging and appreciative of everyone, or as Hurtado et al. put it: "When students feel that they are valued and that faculty and administrators are devoted to their development, they are less likely to report racial/ethnic tension on campus" (1998, p. 287). In order to achieve this they advise campus leaders to make sure that the "perspectives of all members of the campus community are considered" (Hurtado et al., 1998, p. 292). For that reason the racial and ethnic diversity among the faculty at Medgar Evers, which according to John and Gabriela reflects the student population, is an important resource. Yet, remembering that students, administrators and faculty can perceive campus climates differently depending on their status and positionality, it seems important that professors are aware of their own biases. Gladys agrees with this argument and makes a point for the need of self-reflection: “It's very easy to say, you know, 'I'm--I'm accepting of diversity.' ... it's very easy when you are a minority, um, to be comfortable in your minority niche. ... And then really being true to, if I say ... I am for diverse students becoming educated. What do I have to do in myself to make that happen?"

While there can not be a simple or static answer to this important question, we observed several practices at Medgar Evers that evidence appreciation and valuation of diversity. John is a 
staff member who told us several anecdotes of his voluntary efforts to create a welcoming space and friendly relations with underrepresented student groups. He demonstrated a strong interest in students' linguistic varieties as well as their cultural heritage. But there have also been more institutionalized efforts to create spaces for ethnic identities of minorities. Scholarship on college diversity recognizes the important role of "ethnic student organizations and other student support services" (Hurtado et al., 1998, p. 292). One example is the previously mentioned Association of Latin American Studies. It was founded at Medgar Evers in 2008 with the aim to create a space for Latin@students as a minority to share their cultural heritage, discuss social issues and have their voices heard (ALAS n.d.a). The student testimonies the association has published express gratitude to the club for offering them a space to identify as Latin@s, to learn about their cultural and linguistic heritage, as well as the history of Latin@s in the U.S., their marginalization and struggles, and not least to exchange with peers and make friends.

While critics might argue that ethnic student associations intensify notions of racial/ethnic difference and are thus more likely to increase racial separation on campus, students in several testimonies express appreciation for the college and suggest that joining the club has helped them to feel less disconnected to the campus community. Students also mentioned that ALAS has strengthened them personally and professionally: "By participating in this club, I learned more about myself, and, as a teacher, understand Latinos in the classroom and become more aware of being a culturally responsive teacher in helping them and all of my students achieve academic success." (Stephanie, in ALAS, n.d.b). Moreover, in accordance with the previously mentioned suggestion that acknowledging the experiences of nonblack minorities could strengthen ties between groups, some students express the wish for an adoption of curricula in order to include more cultural diversity.

The overall picture drawn by all of the testimonies strongly affirms the notion that “"same-race' peers and environments" (Hurtado, 2007, p.188) can be benefits for students in diverse institutions. Currently, ALAS is not as active as it used to be because the faculty member who was its main advisor had to withdraw her engagement from the club and there was no other professor willing to take on this responsibility. This indicates that the guidance, which the 
institutional facilitation of racially diverse groups requires, needs to be adequately recognized and honored. Ideally professors should be rewarded for the support they provide, for example by a reduction of hours to teach. This does not only apply to ALAS, but it could also encourage other members of racial or ethnic minorities within the college community to organize spaces that can be empowering for its members.

There is no easy answer to the challenge of maintaining Medgar Evers' identity and its important function for black students while being a racially and ethnically diverse institution. But it seems promising to encourage valuation and awareness for different minority experiences both within classes and through ethnic student associations. These practices should by no means be seen as a challenge to the centrality of teaching about black history and present injustices, but as an addition. Faculty and administrators should help students to not only value differences, but also see commonalities through cross-racial dialogue and cooperation. This way it could be a space where coalitions are built for the fight for greater social justice in broader society where white supremacy prevails. As common action can facilitate binding experiences, this could also advance a sense of recognition and belonging among students. Acting and educating towards such goals reflects the original pedagogical mission of Medgar Evers, of which the professors and administrators are well aware. We are optimistic that the previously sketched gap is not all too difficult to bridge because it seems as though the scholarship on campus diversification as well as Medgar Evers' pedagogical mission have 'proceeded on parallel tracks'; both approaches aim to advance student awareness of social problems through dialogue, reflection, social critique and commitment to change (Hurtado, 2007, p. 187). Moreover, the college's own history and mission, along with its diverse faculty and its students seem to be the ideal requisites to put these goals into practice.

\section{Conclusion}

Although the initial aim of this project was to examine the linguistic diversity of Medgar Evers and how the changing cultural landscape of Brooklyn, New York was influencing it, our participants revealed an interconnected web of ethno-linguistic interactions between the key stakeholders at Medgar Evers: students, staff, faculty, and administration. These interactions 
underscore the challenges all parties face: As the school continues to attract more minoritized ethnic populations, administrators and faculty face a choice between leaving students behind and reaffirming their commitment to social transformation.

Some participants view the breadth of linguistic practices discussed and employed throughout these oral histories as a challenge. The need to use an idealized "standard" or "correct" English was a recurring theme across the interviews. Minoritized individuals who use language varieties that are considered unofficial, dialects or slang - in contrast to white, middle class, monolingual standards - still face racialization of their language. In order to live up to the college's goals, educators should challenge hegemonic language ideologies by establishing translanguaging pedagogies, which acknowledge and support the existence of variation.

At Medgar Evers, the population of minoritized students who do not identify as black has increased, yet participants from underrepresented ethno-linguistic backgrounds continue to feel like outsiders. Thus far, scholars have paid little attention to the specific challenges of the diversification of predominantly non-white institutions and further research in this direction is necessary. Yet, it seems recommendable that Medgar Evers should not abandon its connection to the Civil Rights and Black Campus movements. Instead, a dynamic approach that values the complexity of diverse ethno-linguistic backgrounds could bring students and educators from different cultural groups together in empathy through dialogical action (Freire, 1970/2000, Celic and Seltzer, 2011, p. 4). This should include tangible steps taken both in and out of the classroom, while the efforts of educators who provide extracurricular support for students should be adequately recognized. Accordingly the strengths and resources of the college could be used to create an environment that includes every student and educates them to become critical participants who are aware of the past and prevailing injustices different groups have experienced.

Fortunately for Medgar Evers, there are members of faculty and administration who already employ critical pedagogies. From exploring language variation in classes to creating safe spaces for students from different backgrounds, the strategies employed by participants are rich and varied. The institution faces a challenging, but bright future, so long as it continues to show 
solidarity with all stakeholders, to gather input from students and community members, and to strive to move people "from marginality to mattering." A university such as Medgar Evers, in which all levels of stakeholders express enthusiasm for an oral history project and earnestness about both its challenges and assets, is in a ripe position to transform its challenges into new opportunities.

\section{Acknowledgements}

Nicholas Barrington contributed to the planning of this research, to the data collection and analysis and to some of the drafting of a pre-acceptance version of this paper. We would like to thank him for his contribution, while assuming that all words, reflections, possible errors and omissions in this final accepted version are our own.

\section{References}

Association of Latin American Studies. (n.d.a). History. Retrieved from https://meccuny.digication.com/ALAS/Welcome/published.

Association of Latin American Studies. (n.d.b). Member testimonials. Retrieved from https://mec-cuny.digication.com/ALAS/Why_ALAS_-_Member_testimonials

Bailey, E. CUNY Medgar Evers Cöllege. ${ }^{-}$Retrieved from http://www.stateuniversity.com/universities/NY/City_University_of_New_York_Medgar Evers_College.html.

Bakhtin, M. M. (1981). The dialogic imagination: Four essays (M. Holquist, Ed.). Austin: University of Texas Press. DOI: 10.2307/40136453.

Banks, J. A., \& Mcgee Banks, C. A. (2012). Multicultural education: Issues and perspectives $\left(8^{\text {th }}\right.$ ed.). Hoboken: Wiley.

Blommaert, J. (2006). Language Policy and National Identity. In Ricento, T. (Ed.). (2006). An introduction to language policy: Theory and method. London: Blackwell.

Busch, B. (2014). Building on heteroglossia and heterogeneity: The experience of a multilingual classroom. Educational Linguistics 20, 21-40. DOI: 10.1007/978-94-007-7856-6_2.

Celic, C. \& Seltzer, K. (2011). Translanguaging: A CUNY-NYSIEB guide for educators. New York, NY: CUNY-NYSIEB.

City of New York. (2016). NYC Crime Map. Retrieved from https://maps.nyc.gov/crime/.

Chang, M. J. (1996). Racial diversity in higher education: Does a racially mixed student population affect educational outcomes? (Unpublished doctoral dissertation). University of California, Los Angeles: Los Angeles.

Charity Hudley, A.H. \& Mallinson, C. (2013). We Do Language. English Language Variation in the Secondary English Classroom. New York, NY: Teachers College Press. DOI: 10.1080/1554480X.2014.926052. 
CUNY Office of Institutional Research and Advancement (2015). Total enrollment by race/ethnicity and college: Percentages Fall 2014. Retrieved from http://www.cuny.edu/irdatabook/rpts2_AY_current/ENRL_0015_RACE_TOT_PCT.rpt.p df.

Davis, J. F. (2001). Who is Black? One Nation's Definition. 10 anniversary ed edition. Penn State University Press. University Park. Retrieved from http://www.cuny.edu/irdatabook/rpts2_AY_current/ENRL_0015_RACE_TOT_PCT.rpt.p df. DOI: $10.2307 / 4612582$.

Duster, T. (1993). The diversity of California at Berkeley: An emerging reformulation of "competence" in an increasingly multicultural world. In B. W. Thompson \& Sangeeta Tyagi (Eds). Beyond a dream deferred: Multicultural education and the politics of excellence (pp. 231-255). Minneapolis, MN: University of Minnesota Press.

Flores, N, \& Rosa, J. (2015). Undoing appropriateness: Raciolinguistic ideologies and language diversity in education. Harvard Educational Review 85(2), 149-171. DOI: 10.17763/0017-8055.85.2.149.

Freire, P. (1970/2000). Pedagogy of the oppressed. (M. B. Ramos, Trans.). New York, NY: Bloomsbury.

Garcia, O. \& Wei, L. (2014). Translanguaging: Language, Bilingualism and Education. New York: Palgrave Macmillan. DOI: 10.1057/9781137385765.

hooks, b. (1994). Teaching to transgress. New York, NY: Routledge. DOI: $10.4324 / 9780203700280$.

Holborow, M. (2015). Language and neoliberalism. New York, NY: Routledge. DOI: $10.4324 / 9781315718163$.

Hurtado, S. (2007). Linking diversity with the educational and civic missions of higher education. The Review of Higher Education 30(2): 185-196. DOI: 10.1353/rhe.2006.0070.

Hurtado, S., Milem, J. F., Clayton-Pedersen, A. R., \& Allen, W. R. (1998). Enhancing campus climates for racial/ethnic diversity: Educational policy and practice. The Review of Higher Education 21(3): 279-302. DOI: 10.1353/rhe.1998.0003.

Ippolito, K. (2007). Promoting intercultural learning in a multicultural university: Ideals and realities. Teaching in Higher Education 12(5-6): 749-763. DOI: 10.1080/13562510701596356.

Lippi-green, R. (1997). English with an accent: Language, ideology, and discrimination in the United States. London and New York: Routledge

Medgar Evers College. (n.d.a). History. Retrieved from http://www.mec.cuny.edu/AboutMEC/History.aspx

Medgar Evers College. (n.d.b.). Mission statement. Retrieved from http://www.mec.cuny.edu/AboutMEC/Office-of-The-President/Mission-Statement.aspx.

Medgar Evers College (2013) The Medgar Evers College Five Year Strategic Plan. Retrieved from http://www.mec.cuny.edu/AboutMEC/Office-of-The-President/MissionStatement.aspx 
Oguntoyinbo, L. (2015). The Influx of Latino Students at Historically Black Colleges. The Atlantic. Retrieved from www.theatlantic.com/education/archive/2015/09/hbcus-morelatino-students/407953/.

Rogers, I. H. (2012). The black campus movement and the institutionalization of Black Studies, 1965-1970. Journal of African American Studies 16: 21-40. DOI: 10.1007/s12111-0119173-2

Shopes, L. (2002). What is oral history? Retrieved from http://historymatters.gmu.edu/mse/oral/what.html

Smedley, B. D., Myers, H. F., \& Harrell, S. P. (1993). Minority-status stresses and the college adjustment of ethnic minority freshmen. The Journal of Higher Education 64(4): 434452. DOI: $10.2307 / 2960051$

Tollefson, J.W. (2000). Language ideology and language education. In J. Shaw, D. Lubelska \& M. Noullet (Eds.), Partnership and interaction: Proceedings of the fourth international conference on language and development (pp. 43-52). Bangkok: Asian Institute of Technology.

Woolard, K. (1998). Language ideology as a field of inquiry. In B. Schieffelin, K. Woolard, P. Kroskrity (Eds), Language ideologies: Practice and theory (3-49). New York: Oxford Univ. Press.

Zack, N. (1995). American Mixed Race: The Culture of Microdiversity. Lanham, Md.: Rowman \& Littlefield Publishers.

\begin{abstract}
Notes
1. Referred to as "Medgar Evers" throughout the rest of the paper, except when specifically mentioning the man.

2. In the United States, any person with any known African black ancestry is considered black. This definition reflects the long experience with slavery and later with the caste-like Jim Crow system of segregation. However, because that category has a definite status position in society it has become a self-conscious social group with an ethnic identity (Davis, 2001). People of color is a term that describes a person with ancestry from the racial or ethnic groups in the United States that historically were or currently are targeted by racism, including people with African, Native American, Asian, or Latino ancestry. The term draws attention to the fundamental role of racialization in the United States (Zack, 1995). Tuman argues that the term people of color unites disparate racial and ethnic groups into a larger collective in solidarity with one another (2003). The expression non-black students of color thus refers to all students who are experiencing racialization in the US but who are not considered black.

3. We utilize quotes here to maintain that there is a diversity of black identities - Afro-Caribbean, African American, etc.

4. Since the testimonials are published with the authors' full names online, they are not made anonymous.

5. They preferred to remain completely anonymous.
\end{abstract}

Author information: Hannah Göppert is a visiting student at the Sociology Department of CUNY Graduate Center, New York City. She is based at Humboldt University in Berlin, where she is pursuing a MA in Social Sciences and investigating the teaching of German as a second language to refugees and migrants. She also spent six months at the Political Science Department of Universidad Pompeu Fabra, Barcelona, during her undergraduate studies. Her research interests include citizenship \& migration, race/ethnicity as well as urban and educational inequality.

Email: goepperh@sowi.hu-berlin.de

Author information: Andrea Springirth is a Master's student in the M.A. in Liberal Studies Program at the CUNY Graduate Center and has had the fortunate opportunity of conducting the majority of her coursework over the past 
two years in the Anthropology Department. She has a particular interest in discourse and social justice movements, and is currently investigating how language is used to normalize certain ideas about advocacy within the nonhuman animal rights movement. Andrea holds a B.A. in Romance Languages from the University of Maryland, College Park. When not researching or writing for school, she is rehabilitating wildlife and volunteering at local animal sanctuaries.

Email: aspringirth@gradcenter.cuny.edu

To cite this article:

Göppert, H., \& Springirth, A. (2016). From marginality to mattering: Linguistic practices, pedagogies and diversities at a community-serving senior college. Bellaterra Journal of Teaching \& Learning Language \& Literature, 9(2), 5377. DOI: http://dx.doi.org/10.5565/rev/jt13.678

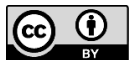

